\title{
Antioxidant treatment improves streptozotocin-induced diabetic alterations in fast twitch skeletal muscles of rats
}

\author{
Zeinab Abdel Hafeez Al-Refaie ${ }^{1}$ and Dina Sabry ${ }^{2}$ \\ ${ }^{1}$ Lecturer of Physiology, ${ }^{2}$ Lecturer of Biochemistry. \\ Physiology Department and Medical Biochemistry Department, \\ Kasr Al-Aini, Faculty of Medicine, Cairo University, Egypt.
}

\begin{abstract}
Background and objective: Diabetes mellitus affects skeletal muscle and free radicals are probably implicated in the manifestations of diabetes complications. Antioxidants have been proposed as therapeutic strategies to protect against diabetes-induced muscle dysfunction. The present study aimed to investigate and compare the effects of vitamin E or selenium on fast twitch gastrocnemius muscle of streptozotocine induced type 2 diabetic rats via recording twitch tension, time to peak tension, half relaxation time and peak tetanic tension and determination of muscle malondialdehyde and glutathione peroxidase as markers for oxidant status, specially, for our knowledge, the effects of vitamin $E$ or selenium on contractile parameters of diabetic fast twitch muscles have not been previously investigated.

Material and methods: 24 male rats of local breed were randomly divided into 4 groups $(n=6)$, control group, diabetic group in which diabetes was induced by i.p. injection of streptozotocin $40 \mathrm{mg} \cdot \mathrm{kg}^{-1}$, vitamin E supplemented diabetic group (600 $\mathrm{mg} . \mathrm{kg}^{-1}$ daily) and selenium supplemented diabetic group (5 micromole. $\mathrm{kg}^{-1}$ daily) for 4 weeks starting 3 days after induction of diabetes.

Results: Diabetes significantly reduced twitch tension and peak tetanic tension of gastrocnemius muscle with no significant change in time to peak tension and half relaxation time. Vitamin $E$ or selenium administration to diabetic rats reversed the oxidative imbalance and improved muscle contractile status with more significant effect in selenium supplemented rats.

Conclusion: Vitamin E or selenium can protect against the alterations in fast twitch muscle properties associated with diabetes.
\end{abstract}

Key words: Diabetes, Fast twitch fibers, vitamin E, Selenium.

\section{INTRODUCTION}

Diabetes mellitus is a syndrome of altered metabolism characterized by chronic hyperglycemia due to an absolute deficiency of insulin secretion and/or insulin resistance. Diabetes is increasing throughout the world and is currently considered one of the main threats to human health in the $21 \mathrm{st}$ century. It is estimated that $\sim 100$ million individuals currently suffer from diabetes, with more than 16 million diabetics in the United States alone. Considerable progress has been made in understanding the underlying 
molecular mechanisms of diabetic complications, and new treatment modalities are beginning to appear in the clinical arena ${ }^{(\mathbf{1})}$.

Diabetes is known to alter contractile and electrical characteristics of skeletal muscles, it is clear that the effects of diabetes on skeletal muscle function differ from one muscle to another and this has been related to muscle fiber type distribution ${ }^{(2)}$.

Skeletal muscle fibers are divided according to the myosin heavy chain isoform (MHC) into slow (MHC I) and 3 fast (MHC IIA, IIX and IIB) fiber types. Patients suffering from noninsulin-dependent diabetes are insulin resistant in their skeletal muscles but are generally normal when it comes to skeletal muscle fiber composition ${ }^{(3)}$.

There is substantial evidence that hyperglycemia results in the generation of reactive oxygen species ${ }^{(4)}$, depletes natural antioxidants, impairs the prooxidant / antioxidant balance and increases oxidative stress which contributes to the progression of diabetes and its complications ${ }^{(5)}$. Promising strategies using antioxidant compounds to prevent oxidative damage in diabetes have been proposed $^{(6)}$.

As far as skeletal muscle is concerned, it has been demonstrated that oxidative stress affects genes involved in protein synthesis ${ }^{(7)}$ and abundant evidence implicates oxidative stress as a potential regulator of proteolytic pathways in the muscle and can be involved in the molecular regulation of muscle atrophy attributable to prolonged disuse ${ }^{(8)}$.

Moreover the skeletal muscle mitochondrial DNA has been shown to be a potential site for oxidative stress resulting in increased DNA damage ${ }^{(\mathbf{9})}$.

Contracting skeletal muscle generates reactive oxygen species that can induce changes in gene expression or cell damage depending upon the pattern of production and the endogenous protective systems. The hypothesis is presented that skeletal muscle uses contraction-induced reactive oxygen species as signals to induce adaptive responses including maintenance of oxidative homeostasis and prevention of oxidative damage ${ }^{(\mathbf{1 0})}$.

Studies using single muscle fibers have shown that myosin motor function is inhibited by the excess generation of reactive oxygen species leading to reduction of muscle work and power output $^{(11)}$.

Increased reactive oxygen species and oxidative stress also interferes with insulin signaling through phosphatidylinositol 3-kinase (PI3K) and its downstream protein kinase $\mathrm{B}$ (Akt) signaling pathways. The inhibition of PI3K/Akt signaling reduces skeletal muscle glucose transport $^{(\mathbf{1 2})}$.

Free radicals and reactive oxygen species as superoxide, hydrogen peroxide and peroxynitrite are produced in the body as a result of aerobic metabolism; they can damage genetic material, cause lipid peroxidation in the cell membrane and inactivate membrane-bound enzymes. Antioxidative defenses against free radicals and reactive species include vitamin $\mathrm{C}$, vitamin $\mathrm{E}$, beta carotene and trace elements including zinc and selenium $^{\mathbf{( 1 3 )}}$.

Vitamin E exerts a protective role against free radical damage; its biological activity is generally believed 
to be due to its ability to inhibit lipid peroxidation in biological membranes by scavenging the chain-propagating peroxyl radicals $(\mathrm{ROO})^{(\mathbf{1 4})}$.

A new non-antioxidant role of vitamin $\mathrm{E}$ has been established through signal transduction and gene regulation studies which showed its inhibitory effect on cell proliferation and protein kinase $\mathrm{C}$ activity. More recently, a vitamin $\mathrm{E}$ binding protein with possible receptor function has been discovered. Vitamin E deficiency has been associated with various disorders, particularly atherosclerosis, ischemic heart disease, and the development of different types of cancer ${ }^{(15)}$.

As regard skeletal muscles, vitamin $\mathrm{E}$ has been shown to reduce contraction-mediated oxidative damage. It is postulated that vitamin $\mathrm{E}$ deficiency would adversely affect muscle contractile function resulting in a more rapid development of muscular fatigue during exercise ${ }^{(\mathbf{1 6})}$.

Moreover, vitamin E pretreatment prevented ATP depletion in skeletal muscle in experimental hind limb ischemia/reperfusion models ${ }^{(\mathbf{1 7})}$. Also vitamin $\mathrm{E}$ attenuated skeletal muscle mitochondrial DNA degradation and depletion induced by ethanol in mice, an effect which could be useful in persevering drinkers ${ }^{\mathbf{( 1 8 )}}$. In addition, previous studies demonstrated that Vitamin E therapy improved cardiac and skeletal muscle bioenergetics in patients with Friedreich's ataxia and could be a disease-modifying strategy in this neurodegenerative disorder ${ }^{(\mathbf{1 9})}$.

Selenium is an essential micronutrient that functions mainly through Se-dependent proteins. Glutathione peroxidase 1(GPX 1) is the first identified and the most abundant selenoprotein in mammals. The biochemical and physicochemical properties of selenium result in the unique redox characteristics of this enzyme and its ability to reduce $\mathrm{H}_{2} \mathrm{O}_{2}$ and organic hydroperoxides ${ }^{(4)}$.

Besides its antioxidant effect, selenium influences a number of endocrine processes, most notably, those involved in thyroid hormone synthesis and metabolism. Selenium has also been implicated in proper function of immune system, viral suppressions, delaying aging process, enhancing sperm motility and reducing the risk of miscarriage. Great efforts have been directed towards the synthesis of stable organoselenium compounds that can be used as an antioxidatives, enzyme modulators, antimicrobials, antiviral, and antihypertensive and cytokine inducers ${ }^{(20)}$.

Concerning skeletal muscles, selenium is required to maintain an optimal rate of muscle cell differentiation $^{(21)}$. Skeletal muscle disorders manifested by muscle pain, fatigue, weakness, and serum creatine kinase elevation have been reported in patients with selenium deficiency due to insufficient selenium intake in low soil-selenium areas, parenteral or enteral nutrition, malabsorption, and chronic conditions associated with oxidative stress $^{(22)}$.

Besides to skeletal myopathy, selenium deficiency can cause cardiomyopathy and sudden death, that's why careful monitoring for selenium deficiency is important in susceptible patients ${ }^{(23)}$.

Selenium and vitamin E deficiency has been shown to result in a fatal myopathy in guinea pigs that is 
associated with lipid peroxidation in the affected muscles with severe histological muscle necrosis ${ }^{(24)}$.

The present work aimed to study the potential protective effects of vitamin $E$ or selenium on the contractile parameters of the fast twitch gastrocnemius muscle in streptozotocin-induced diabetic rats, especially data about the possible effects of vitamin $E$ or selenium on these parameters are lacking.

\section{MATERIAL \&METHODS}

\section{Chemicals:}

Streptozotocin, vitamin E, arachis oil and selenium were purchased from Sigma Chemical Company, St. Louis, Missouri, USA.

Animals:

24 male rats of the local breed weighing 150 - 200 gram were used in this study, they were kept in the animal house, Kasr Al-Aini faculty of medicine, Cairo University. The rats had free access to standard rat chow and water ad libitum, they were kept at $22 \pm 1^{\circ} \mathrm{C}$ temperature at 12 hour darklight cycles.

\section{Experimental groups:}

Rats were randomly divided into 4 groups, each one included 6 rats:

Control group (Group I), received i.p. injections of $0.1 \mathrm{~mol} / \mathrm{L}$ citrate buffer (pH 4.5).

Diabetic group (Group II), received i.p. injections of streptozotocin (STZ) $40 \mathrm{mg} \cdot \mathrm{kg}^{-1}$ dissolved in $0.1 \mathrm{~mol} / \mathrm{L}$ citrate buffer $(\mathrm{pH} 4.5)^{(25)}$. Diabetic group treated with vitamin E (Group III), diabetes was induced as in group 2 , three days later animals started to receive vitamin E $600 \mathrm{mg} \cdot \mathrm{kg}^{-1}$ per day dissolved in arachis oil i.m. for 4 weeks ${ }^{(26)}$. Diabetic group treated with selenium (Group IV), diabetes was induced as in group 2, three days later animals started to receive sodium selenite 5 micromole. $\mathrm{kg}^{-1}$ per day dissolved in distilled water i.p. for 4 weeks $^{(27)}$.

\section{The in-situ isometric measures:}

After 4 weeks each animal was anaesthetized by inhalation of ether, the right limb was fixed, skin was opened and the distal tendon of the fast twitch gastrocnemius muscle ${ }^{(\mathbf{2 8})}$ was sectioned and attached to a force transducer (Intercept TSC286/1). The output signals were then fed to a bipotential amplifier (Intercept) and displayed using personal computer-based data capture and acquisition software (Phys 4 intercept). The muscle was activated with electrodes by using monophasic rectangular pulses of 0.2 milliseconds duration of anodal current. Adjustments to muscle length were made to find optimal length for maximum twitch force. Stimulus intensity was increased until maximum twitch force was obtained. A minimum of 2 tetanic contractions were made with the greatest being taken, a recovery interval of 5 minutes was taken between each contraction $^{(29)}$. Using screen cursors, the following parameters were recorded from each gastrocnemius muscle:

Twitch measurements: tension (expressed as screen units), time to peak tension and half relaxation time (expressed in milliseconds.)

Tetanic contraction measurement: peak tetanic tension (expressed as screen unites).

The gastrocnemius muscles were then excised and frozen for further determination of malondialdehyde (MDA) and glutathione peroxidase 
(GPX) levels as markers of oxidative stress.

\section{Spectrophotometric determination of MDA:}

Frozen skeletal tissues were minced and homogenized in $1 \mathrm{ml}$ of Tris HCL (10 Mm pH 7.5), NaCl, (150 $\mathrm{Mm})$, tritonX 100, $(1 \% \mathrm{v} / \mathrm{v}))$, and PMSF $(10 \mathrm{Mm})$. Lipid peroxidation was determined by measuring MDA in skeletal tissue homogenates using thiobarbituric acid TBARS method according to Ohkawa et al. ${ }^{(30)}$.

An aliquot $(100 \mu \mathrm{L})$ of the homogenate was added to a reaction mixture containing $100 \mu \mathrm{L}$ of $8.1 \%$ sodium dodecyl sulfate (SDS), $750 \mu \mathrm{L}$ of $20 \%$ acetic acid ( $\mathrm{pH} 3.5$ ), $750 \mu \mathrm{L}$ of $0.8 \%$ thiobarbituric acid (Sigma) and $300 \mu \mathrm{L}$ distilled water. Samples were then boiled for $1 \mathrm{~h}$ at $95^{\circ} \mathrm{C}$ and centrifuged at $4000 \mathrm{x}$ g for $10 \mathrm{~min}$. The absorbance of the supernatant was measured by spectrophotometry at 650 $\mathrm{nm}$. The TBARS content was expressed as $\mathrm{nmol} / \mathrm{mg}$ tissue protein.

\section{Spectrophotometric determination of} GPX:

Samples were homogenized in phosphate buffer $(0.1 \mathrm{~mol} / \mathrm{l}, \mathrm{pH} 7.4)$ and centrifuged for $20 \mathrm{~min}$ at $3000 \mathrm{x} \mathrm{g}$. The whole procedure was performed at $4^{\circ} \mathrm{C}$. The reaction mixture contained $100 \mu \mathrm{l}$ of NADPH solution (8.4 $\mathrm{mmol} / \mathrm{l}$, Sigma), $10 \mu \mathrm{l}$ glutathione reductase (GSSG-R, $100 \quad \mathrm{U} / \mathrm{mg}$ protein $/ \mathrm{ml}$, Sigma), $10 \mu \mathrm{l}$ sodium azide $(1.125 \mathrm{~mol} / \mathrm{l}, \quad$ Sigma), $\quad 100 \mu \mathrm{l}$ glutathione (0.02 mol/l, GSH, Sigma) filled with phosphate buffer $(0.05$ $\mathrm{mol} / \mathrm{l}, \mathrm{pH} 7.0$ ) up to the volume of 2.8 $\mathrm{ml}$ and $100 \mu \mathrm{l}$ of supernatant. The rate of GSSG formation was measured by the following decrease in absorbance of the mixture at $340 \mathrm{~nm}$, as NADPH was converted to $\mathrm{NADP}^{+}$, between 2 nd and 4th minute after initiation of the reaction. The activity was assessed as $\mathrm{nmol} / \mathrm{mg}$ tissue protein, Nakamura et al. $^{(31)}$.

\section{Protein content estimation:}

The protein content of the supernatants was determined using Lowry method (32) using bovine serum albumin as standard.

\section{Statistics:}

The results were expressed as mean values \pm SD. Comparisons between groups were carried out by one-way analysis of variance (ANOVA) for multiple comparisons. Correlation coefficients were obtained using Pearson's correlation coefficient, a $\mathrm{p}$ value $<0.05$ was regarded as statistically significant.

\section{RESULTS}

\section{Muscle contractile parameters: [Table 1 and Figure 1]}

Results of isometric measures showed that peak tetanic tension (PTT) and twitch tension (TT) were significantly reduced in diabetic rats (group II), compared to control rats (group I), ( $19.18 \pm 1.46$ and $7.7 \pm 0.64$ in group II versus $27.62 \pm 1.68$ and $10.33 \pm 0.74$ in group I respectively, $\mathrm{P}$ $<0.001$ for both parameters).

Vitamin E supplementation (group III) significantly attenuated the reduction in PTT and TT in diabetic rats $(23.05 \pm 1.72, \mathrm{P}<0.001$ and $8.48 \pm$ $0.56, \mathrm{P}<0.05$ respectively).

Similarly diabetic animals supplemented with selenium (group IV) showed a significant increase in PTT and TT when compared to group II $(25.75 \pm 0.96$ and $9.7 \pm 0.61$ 
respectively, $\mathrm{P}<0.001$ for both parameters).

Administration of selenium attenuated the reduction of PTT and TT of diabetic rats more significantly than vitamin $\mathrm{E}(\mathrm{P}<0.01)$.

There was no significant change in the time to peak tension (TPT) or half relaxation time $(1 / 2 \mathrm{RT})$ when the diabetic group values were compared to those of control group.

Muscle malondialdehyde (MDA): [Table 2 and Figure 2]

Diabetes significantly increased muscle MDA from $0.16 \pm 0.02$ in group I to $0.34 \pm 0.15 \mathrm{nmol} / \mathrm{mg}$ in group II (P $<0.05)$.

Vitamin E (group III) or selenium (group IV) supplementation lowered muscle MDA level $\quad(0.22 \pm 0.11$ and $0.18 \pm 0.02 \mathrm{nmol} / \mathrm{mg}$ respectively).

Muscle Glutathione peroxidase (GPX): [Table 2 and Figure 2]

GPX muscle level in diabetic group (group II) showed a significant decline in comparison to control group (group I) $(0.91 \pm 0.19$ and $2.3 \pm 0.45$ $\mathrm{nmol} / \mathrm{mg}$ respectively, $\mathrm{P}<0.001)$.

The decrease in muscle level of GPX in diabetic rats was ameliorated by administration of vitamin E (group III) or selenium (group IV) (1.73 \pm 0.21 and $2.11 \pm 0.25 \mathrm{nmol} / \mathrm{mg}$ respectively). The increase in muscle level of GPX was more significant in selenium treated group $(\mathrm{P}<0.05)$.

\section{Correlation and regression:}

Significant negative correlations were evident between PTT and MDA in groups III and IV $(\mathrm{r}=0.980, \mathrm{P}<0.01$ and $\mathrm{r}=0.899, \mathrm{P}<0.05$ respectively) and between TT and MDA in the same groups $(\mathrm{r}=0.825, \mathrm{P}<0.05$ and $\mathrm{r}=$ $0.925, \mathrm{P}<0.01$ respectively).

Positive correlation between PTT and GPX was significant in group II ( $\mathrm{r}$ $=0.849, \mathrm{P}<0.05$ ), while $\mathrm{TT}$ positively correlated with GPX in groups III and IV, $(\mathrm{r}=0.964, \mathrm{P}<0.01$ and $\mathrm{r}=0.926, \mathrm{P}$ $<0.01$ respectively). 
Table 1: Effects of vitamin E or selenium on diabetes induced changes in the twitch tension, time to peak tension, half relaxation time and peak tetanic tension of rat gastrocnemius muscle, screen units (mean $\pm \mathrm{SD}$ ).

\begin{tabular}{|lllll|}
\hline Groups & TT & TPT & 1/2 RT & PTT \\
\hline Control & $10.33 \pm 0.74$ & $39.77 \pm 0.98$ & $32.2 \pm 1.97$ & $27.62 \pm 1.68$ \\
& & & & \\
\hline $\begin{array}{l}\text { Diabetic } \\
n=6\end{array}$ & $7.7 \pm 0.64$ & $41.23 \pm 1.64$ & $32.43 \pm 1.08$ & $19.18 \pm 1.46$ \\
& $\mathrm{P}<0.001^{*}$ & & & $\mathrm{P}<0.001^{*}$ \\
\hline $\begin{array}{l}\text { Diabetic + vitaminE } \\
\mathrm{n}=6\end{array}$ & $8.48 \pm 0.56$ & $40.08 \pm 1.11$ & $31.83 \pm 1.38$ & $23.05 \pm 1.72$ \\
& $\mathrm{P}<0.001^{*}$ & & & $\mathrm{P}<0.001^{*}$ \\
& $\mathrm{P}<0.05^{\dot{Y}}$ & & & $\mathrm{P}<0.001^{\mathrm{Y}}$ \\
\hline $\begin{array}{l}\text { Diabetic + selenium } \\
\mathrm{n}=6\end{array}$ & $9.7 \pm 0.61_{\dot{Y}}$ & $39.78 \pm 1.35$ & $32.1 \pm 1.21$ & $25.75 \pm 0.96$ \\
& $\mathrm{P}<0.001^{\S}$ & & & $\mathrm{P}<0.05^{*}$ \\
\hline
\end{tabular}

* Significant change when compared to control group.

Ý significant change when compared to diabetic group.

$\S$ Significant change when compared to diabetic + vitamin E group.

TT: twitch tension.

TPT: time to peak tension.

1/2 RT: half relaxation time.

PTT: peak tetanic tension.

Table 2: Effects of vitamin E or selenium on diabetes induced changes in the rat gastrocnemius muscle malondialdehyde and glutathioneperoxidase, $\mathrm{nmol} / \mathrm{mg}$ (mean \pm SD).

\begin{tabular}{|cll|}
\hline Groups & MDA & GPX \\
\hline Control & $0.16 \pm 0.03$ & $2.3 \pm 0.45$ \\
$\mathrm{n}=6$ & & \\
\hline Diabetic & $0.34 \pm 0.15$ & $0.91 \pm 0.19$ \\
$\mathrm{n}=6$ & $\mathrm{P}<0.01^{*}$ & $\mathrm{P}<0.001^{*}$ \\
\hline $\begin{array}{c}\text { Diabetic + vitaminE } \\
\mathrm{n}=6\end{array}$ & $0.22 \pm 0.11$ & $1.73 \pm 0.21$ \\
& $\mathrm{P}<0.05^{\dot{\mathrm{Y}}}$ & $\mathrm{P}<0.01^{*}$ \\
& & $\mathrm{P}<0.001^{\dot{\mathrm{Y}}}$ \\
\hline Diabetic + selenium & $0.18 \pm 0.04$ & $2.11 \pm 0.25$ \\
$\mathrm{n}=6$ & $\mathrm{P}<0.01^{\dot{\mathrm{Y}}}$ & $\mathrm{P}<0.001^{\dot{\mathrm{Y}}}$ \\
& & $\mathrm{P}<0.05^{\S}$ \\
\hline
\end{tabular}

* Significant change when compared to control group.

Ý significant change when compared to diabetic group.

$\S$ Significant change when compared to diabetic + vitamin E group.

MDA: malondialdehyde

GPX: glutathione peroxidase 


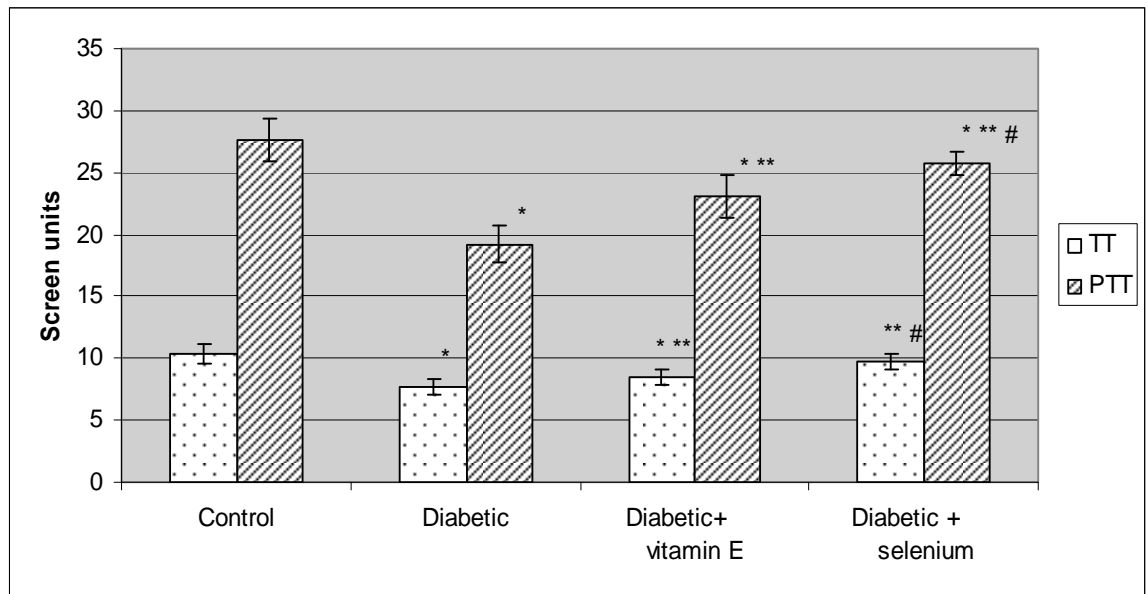

Figure 1: Effects of vitamin $E$ or selenium on diabetes induced changes in the twitch tension (TT) and peak tetanic tension (PTT) of rat gastrocnemius muscle screen units (mean $\pm S D$ ), error bars represent $S D$.

* Significant change when compared to control group.

** Significant change when compared to diabetic group.

\# Significant change when compared to diabetic + vitamin E group.

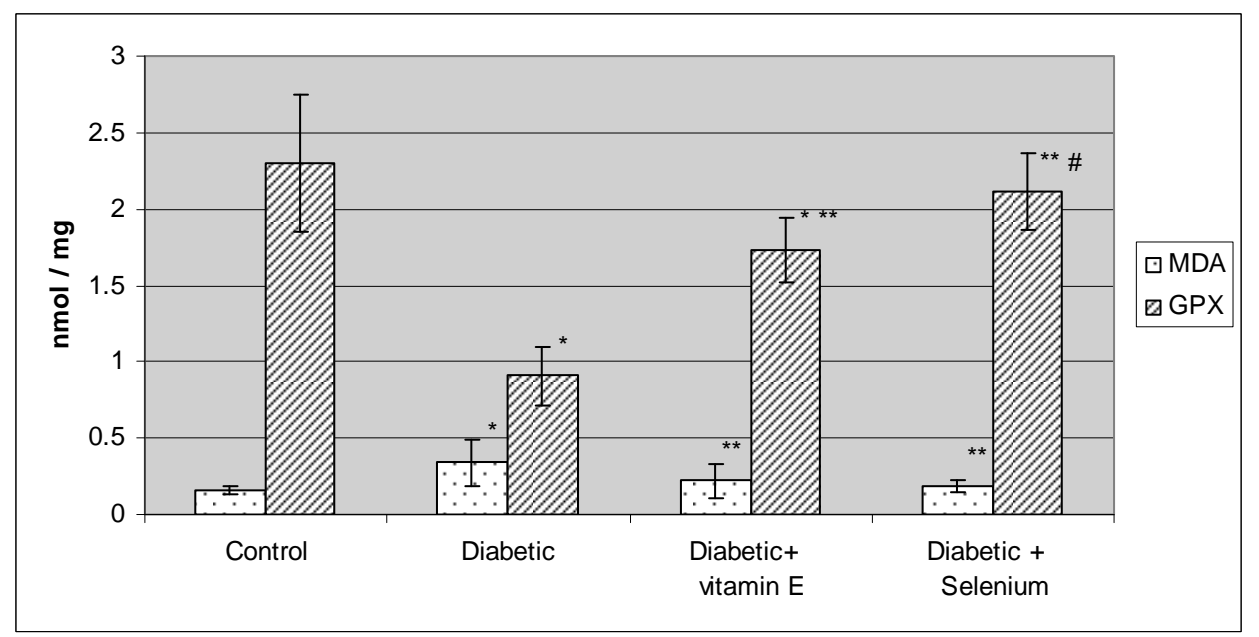

Figure 2: Effects of vitamin $E$ or selenium on diabetes induced changes in the rat gastrocnemius muscle malondialdehyde (MDA) and glutathioneperoxidase (GPX) $\mathrm{nmol} / \mathrm{mg}$ (mean $\pm S D)$, error bars represent $S D$.

* Significant change when compared to control group.

** Significant change when compared to diabetic group.

\# Significant change when compared to diabetic + vitamin E group. 


\section{DISCUSSION}

Functional alterations could be seen in skeletal muscles' contractile properties and may play a role in the pathogenesis of diabetic myopathy.

The present study revealed that peak tetanic tension and twitch tension of fast twitch muscles of diabetic rats were significantly decreased when compared to control rats with no significant change in the time to peak tension or the half relaxation time.

This is in consistence with the previous findings of De Angelis et al. ${ }^{(33)}$, who showed that diabetes induced in rats by injection of STZ $(50 / \mathrm{kg})$, decreased the peak tetanic tension and twitch tension in fast twitch muscles without affecting the temporal properties of a single twitch.

Also in an earlier study done by Cotter et al. ${ }^{(34)}$ diabetes had a nonsignificant effect on speed related contractile parameters in fast muscles 4 months following induction of diabetes, while the tetanic tension was progressively reduced with diabetes duration.

The lack of diabetes-induced effects on the temporal parameters of fast twitch muscles could be explained by the fact that diabetes doesn't produce changes that could affect the time course of force response, unlike the slow twitch muscle fibers, in which diabetes increases the $\mathrm{Ca}^{++}$sensitivity leading to longer duration of twitch response for the same $\mathrm{Ca}^{++}$transient as the force will be activated earlier at lower $\mathrm{Ca}^{++}$and will relax later after $\mathrm{Ca}^{++}$drops to lower levels ${ }^{(35)}$.
It was suggested that the decrease in tetanic tension of fast twitch muscles induced by diabetes, is mainly caused by direct effects on the contractile regulatory system of fast twitch fibers which develop little force ${ }^{(35)}$. Also an excitation contraction uncoupling may contribute to the loss of strength in fast-twitch muscles ${ }^{(36)}$, reduced capacity of the $\mathrm{Na}^{+} \mathrm{K}^{+}$pump and decreased $\mathrm{Na}^{+} \mathrm{K}^{+}$ATPase activity in diabetic skeletal muscle membrane have been previously reported as soon as 5 days following STZ injection, this may lower the excitability and might explain the reduced tension generated by the muscles ${ }^{(33)}$.

Insulin has also been shown to enhance muscle mitochondrial biogenesis and mitochondrial protein synthesis. Thus insulin-induced increase in muscle mitochondrial ATP production might be defective in diabetes ${ }^{(37)}$.

These suggested functional alterations in diabetic skeletal muscles may possibly be the result of dysregulation of intramyocellular fatty acid metabolism ${ }^{(38)}$, the production of advanced glycation end products, glucose auto-oxidation or the increased production of reactive oxygen species ${ }^{(39)}$

The most important finding in the present work, is the improvement of the altered contractile parameters of the fast twitch gastrocnemius muscle of type 2 diabetic rats, following vitamin $\mathrm{E}$ or selenium supplementation with a more significant effect in the selenium supplemented group. 
For our knowledge, no previous studies have demonstrated the effects of these 2 important micronutrients on the fast twitch skeletal muscles in diabetic rats, instead other types of muscle tissue were investigated.

Haidara et al., studied the effect of vitamin $\mathrm{E}$ on the contractility of the diaphragm in type 1 diabetic rats, they observed that vitamin $\mathrm{E}$ significantly increased the height of contraction and delayed the onset of fatigue of the diaphragm of diabetic rats $^{(26)}$

The possible beneficial effects of selenium on diabetic cardiac muscle dysfunction were evaluated by Ayaz et al. ${ }^{(27)}$ who induced diabetes in rats by STZ $50 \mathrm{mg} / \mathrm{kg}$, they were then treated with selenium for 4 weeks. Selenium treatment reversed the prolongation in both action potential duration and twitch duration of the diabetic cardiac muscle. They suggested that the effects of selenium treatment could be related to the restoration of cell glutathione redox cycle.

Our study also revealed a significant increase in malondialdehyde MDA, an indicator of lipid peroxidation, and a significant decrease in glutathione peroxidase GPX, an antioxidant enzyme, in the gastrocnemius muscles of type 2 diabetic rats when compared to those of control group. These changes were reversed by administration of either vitamin $\mathrm{E}$ or selenium which restored the muscle GPX level more significantly. These data suggest that the altered prooxidant/antioxidant balance may contribute to the changes in muscle contractile parameters, especially that correlation and regression studies revealed many significant relations between muscle contractile parameters and markers of oxidative stress.

In accordance with our finding, Aragno et al. $^{(\mathbf{4 0})}$ demonstrated an increase in prooxidant compounds and a decrease in antioxidant levels in the gastrocnemius muscle of diabetic rats 2 weeks following induction of diabetes by STZ. $(50 \mathrm{mg} / \mathrm{kg})$. Oral administration of vitamin $\mathrm{E}$ at a dose of $400 \mathrm{mg} \cdot \mathrm{kg}^{-1}$ per day for 3 weeks, significantly decreased $\mathrm{H}_{2} \mathrm{O}_{2}$ levels and improved the antioxidant level.

The more significant effect of selenium over vitamin $\mathrm{E}$ in the current experiment, could be explained by the observation of Faure, ${ }^{(41)}$ who reported that the mechanism of free radical overproduction in diabetes originates from the mitochondria, so in such condition antioxidant enzymes (in which selenium is incorporated) are more relevant to reduce oxygen species than vitamin $\mathrm{E}$.

In another study, vitamin $\mathrm{E}$ and selenium significantly decreased products of lipid peroxidation and increased glutathione peroxidase in diabetic rats' red blood cells, liver and muscles. These changes were more significant in rats treated with selenium than those treated with vitamin $\mathrm{E}^{(\mathbf{4 2 )}}$.

It is not only the restoration of altered activities of antioxidant enzymes that makes selenium supplementation beneficial in diabetes, but other explanations have been suggested. 
Muller et al. ${ }^{(43)}$ observed an insulinomimetic role for selenium supplementation in type 2 diabetic mice as indicated by better glucose tolerance and lower insulin resistance, while Stapleton, ${ }^{(44)}$ suggested that selenium may activate key proteins involved in the insulin signal cascade.

Besides to the insulinomimetic action of selenium, $\mathrm{Wu}$ et al. ${ }^{(45)}$ suggested that selenium supplementation may have an impact on some gene expression in diabetic rats which may contribute to the regulating effects on diabetes disorders of metabolism.

It was demonstrated also in patients with type 2 diabetes, that selenium enriched diet could efficiently reduc blood glucose, MDA levels and increase GPX activity $^{(46)}$.

The fact that serum levels of selenium were found to be significantly lower in patients with either type 1 or 2 diabetes than in normal subjects ${ }^{(47)}$, points to the importance of dietary supplementation of such micronutrients which could be complementary to classical therapies for preventing and treating diabetic complications.

\section{Conclusion}

Data of the present study demonstrate that supplementation of vitamin E or selenium to type 2 STZdiabetic rats significantly improved the altered contractile parameters of the fast twitch gastrocnemius muscle and corrected the prooxidant/antioxidant status, an effect which was more significant with selenium supplementation. This observation points to the importance of dietary modification to enhance the intake of antioxidants to protect against diabetes-induced muscle dysfunction.

\section{Acknowledgments}

We wish to thank Professor Dr. Mohammad Haidara for his valuable comments during preparation of the manuscript.

\section{REFERENCES}

1. Farhad RD, Yashpal SK. Modulatory effects of HMGCoA reductase inhibitors in diabetic microangiopathy. FASEB J 2004; 18: 805-815.

2. McGuire $M$, Dumbleton $M$, MacDermott M, Bradford A. Contractile and electrical properties of sternohyoid muscle in streptozotcin diabetic rats. Clin Exp Pharmacol Physiol 2001; 28 (3): 184-187.

3. Daugaard JR, Richter EA. Relationship between muscle fiber composition, glucose transporter protein 4 and exercise training: possible consequences in non-insulindependent diabetes mellitus. Acta Physiol Scand 2001; 171 (3): 267-276.

4. James PM, Carol AR, Weipeng M. Development of insulin resistance and obesity in mice over expressing cellular glutathione peroxidase. PNAS 2004; 101(24): 8852-8857.

5. Evans JL, Goldfine ID, Maddux BA, Grodsky GM. Oxidative stress and stress- 
activated signaling pathways: a unifying hypothesis of type 2 diabetes. Endocr Rev 2002; 23 : 599-622.

6. Ziegler D. Therapy with antioxidants in human diabetic neuropathy. J Neurochem 2003; 85: 15-19.

7. Li Y-P, Schwartz RJ, Waddell ID, Holloway BR, Reid MB. Skeletal muscle myocites undergo protein loss and reactive oxygen-mediated NF-kB activation in response to tumor necrosis factor $\alpha$. FASEB $J$ 1998; 12: 871-880.

8. Powers SK, Kavazis AN, DeRuisseau KC. Mechanisms of disuse muscle atrophy: role of oxidative stress. Am J Physiol Regul Integr Comp Physiol 2005; 288(2): R337-344.

9. Sreekumar R, Unnikrishnan J, Fu A. Impact of high fat diet and antioxidant supplement on mitochondrial functions and gene transcripts in rat muscle. Am J Physiol Endocrinol Metab 2002; 282(5): E1055-1061.

10. Pattwell DM, Jackson MJ. Contraction-induced oxidants as mediators of adaptation and damage in skeletal muscle. Exerc Sport Sci Rev 2004; 32(1): 14-18.

11. Vandenboom R. The myofibrillar complex and fatigue: a review. Can J Appl Physiol 2004; 29 (3): 330-356.

12. Sowers JR. Insulin resistance and hypertension. Am J Physiol Heart Circ Physiol 2004; 286(5): H1597-1602.
13. Florence TM. The role of free radicals in disease. Aust N Z J Ophthalmol 1995; 23(1): 3-7.

14. Elena S, Valerian $K$, Derick $H$, Lester P. Free radical recycling and inter-membrane mobility in the anti-oxidative properties of alpha-tochopherol and alphatocotrienol. Free Rad Biol Med 1990; 10: 263-275.

15. Ricciarelli R, Zingg J-M, Azzi A. Vitamin E: protective role of a Janus molecule. FASEB J 2001; 15: 2314-2325.

16. Coombes JS, Rowell B, Dodd SL. Effects of vitamin E deficiency on fatigue and muscle contractile properties. Eur J Appl Physiol 2002; 87(3): 272-277.

17. Punz A, Nanobashvili J, Fuegl A, Huk I, Roth E. Effect of alpha-tocopherol pretreatment on high energy metabolites in rabbit skeletal muscle after ischemia -reperfusion. Clin Nutr 1998; 17(2): 85-87.

18. Mansouri A, Demeilliers $C$, Amsellem S, Pessayre D, Fromenty B. Acute ethanol administration oxidatively damages and depletes mitochondrial DNA in mouse liver, brain and skeletal muscles: protective effects of antioxidants. J Pharmacol Exp Ther 2001; 298(2): 737-743.

19. Lodi R, Hart PE, Rajagopalan B. Antioxidant treatment improves in vivo cardiac and skeletal muscle bioenergetics in patients with Friedreich's ataxia. Ann Neurol 2001; 49(5): 590596.

20. Soriano-Garcia M. Organoselenium compounds as 
potential therapeutic and chemopreventive agents: a review. Curr Med Chem 2004; 11(12): 1657-1669.

21. Ueda $Y$, Whanger PD, Forsberg NE. The effects of selenium deficiency on differentiation, degradation and cell lysis of L8 rat skeletal muscle cells. Biol Trace Elem Res 1999; 69(1): 1-13.

22. Chariot P, Bignani O. Skeletal muscle disorders associated with selenium deficiency in humans. Muscle Nerve 2003; 27(6): 662668.

23. Hiroyuki I, Fumio K, Tatsuo M, Kazuo C. White muscle disease in humans: myopathy caused by selenium deficiency in anorexia nervosa under long term total parenteral nutrition. J Neurol Neurosurg Psychiatry 1999; 67: 829-830.

24. Hill KE, Motley AK, Li X, May J M, Burk RF. Combined selenium and vitamin $\mathrm{E}$ deficiency causes fatal myopathy in guinea pigs. J Nutr 2001; 131(6): 1798-1802.

25. Mondon CE, Jones IR, Azhar S, Hollenbeek CB and Reaven GM. Lactate production and pyruvate dehydrogenase activity in fat and skeletal muscles from diabetic rats. Diabetes, Vol 41, issue 12, copyright .1992 by American Diabetic Association.

26. Haidara M, Ibrahim M, Tuwaijri A, Awadalla S, Yaseen H. Effect of $\alpha$-tocopherol on glucose uptake and contractility in rat skeletal muscle. Med Sci Monit 2003; 9 (5):BR214-217.
27. Ayaz M, Ozdemir S, Ugur $M$, Vassort G, Turan B. Effects of selenium on altered mechanical and electrical cardiac activities of diabetic rat. Arch Biochem Biophys 2004; 426(1): 83-90.

28. Nozais $M$, Merkulova $T$, Keller A. Denervation of rabbit gastrocnemius and soleus muscles: effect on muscle specific enolase. Eur J Biochem 1999; 263(1): 195-201.

29. Chen K, Always S. A physiological level of clenbutrol does not prevent atrophy or loss of force in skeletal muscle of old rats. J Appl Physiol 2000; 89(2): 606-612.

30. Ohkawa H., Ohishi N. and Yagi K. Assay for lipid peroxides in animal tissues by a thiobarbituric acid reaction. Anal.Bioch 1979; 95 (2):351358.

31. Nakamura W, Hosoda S, Hayashi K. Purification and properties of rat liver glutathione peroxidase. Biochim Biophys Acta 1974; 358: 251-261.

32. Lowry, OH, Rosenbrough, NJ, Farr, AL and Randal, RJ. Protein measurement with the folin phenol reagent. J. Biol. Chem. 1951;193: 265-275.

33. De Angelis $K$, Senna $S$, Lrigoyen MC, Cestari SA. Diabetes-induced alterations in latissimus dorsi muscle properties impair effectiveness of dynamic cardiomyoplasty in rats. Artificial Organs 2004; 28 (4): 326-331.

34. Cotter MA, Cameron NE, Robertson S, Ewing I. Polyol pathway-related skeletal muscle 
contractile and morphological abnormalities in diabetic rats. Exp Physiol 1993; 78 (2): 139155.

35. Stephenson GM, O'Callaghan A, Stephenson DG. Single-fiber study of contractile and biochemical properties of skeletal muscles in sreptozotocin-induced diabetic rats. Diabetes 1994; 43(5): 622628.

36. Lesniewski LA, Miller TA, Armstrong RB. Mechanisms of force loss in diabetic mouse skeletal muscle. Muscle Nerve 2003; 28(4): 493-500.

37. Nair KS. Aging muscle. Am J Clin Nutr 2005; 81(5): 953-63.

38. Petersen KF, Shulman GI. Pathogenesis of skeletal muscle insulin resistance in type 2 diabetes mellitus. Am J Cardiol 2002; 90(5A): 11G-18G.

39. Bonnefont-Rousselot D. Glucose and reactive oxygen species. Curr Opin Clin Nutr Metab Care 2002; 5(5): 561-568.

40. Aragno $M$, Mastrocola $R$, Catalano MG, Brignardello E, Danni O, Boccuzzi G. Oxidative stress impairs skeletal muscle repair in diabetic rats. Diabetes 2004; 53: 1082-1088.

41. Faure P. Protective effects of antioxidant micronutrients (vitamin E, zinc and selenium) in type 2 diabetes mellitus. Clin Chem Lab Med 2003; 41(8): 995-998.
42. Naziroglu M, Cay M. Protective role of intraperitoneally administered vitamin $\mathrm{E}$ and selenium on the antioxidative defense mechanisms in rats with diabetes induced by streptozotocin. Biol Trace Elem Res 2001; 79(2): 149-159.

43. Muller AS, Pallauf J, Rafael J. The chemical form of selenium affects insulinomimetic properties of the trace element: investigations in type II diabetic $\mathrm{dbdb}$ mice. $\mathrm{J}$ Nutr Biochem 2003; 14(11): 637-647.

44. Stapleton SR. Selenium: an insulin-mimetic. Cell Mol Life Sci 2000; 57 (13-14): 18741879.

45. Wu Y, Sun Z, Che S, Chang $H$. Effects of zinc and selenium on the disorders of blood glucose and lipid metabolism and its molecular mechanism in diabetic rats. Wei Sheng Yan Jiu 2004; 33(1): 70-73.

46. Skripchenko ND, Sharafetinov Kh Kh, Plotnikova OA, Meshcheriakova VA, Mal'tsev Glu. Effect of selenium enriched diet on lipid peroxidation in patients with diabetes mellitus type 2. Vopr Pitan 2003; 72(1): 14-17.

47. Kljai K, Runje R. Selenium and glycogen levels in diabetic patients. Biol Trace Elem Res 2001; 83(3): 223-229. 
العلاج بمضادات الاكسدة يحسن التغيرات التى يحدثها مرض البول السكرى

$$
\text { على العضلات سريعة الانقباض فى الفئران }
$$

قسم الفسيولوجى و قسم الكيمياء الحيوية الطبية، كلية طب القصر العينى، جامعة القاهرة

مرض البول السكرى يؤثز على العضلات، و العوامل الحرة تلعب دورا فى اعراض

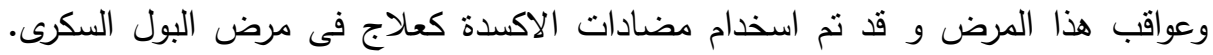

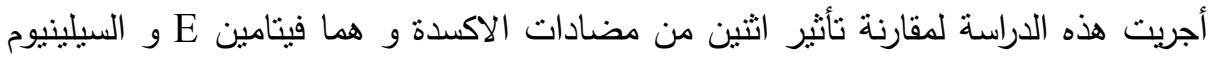

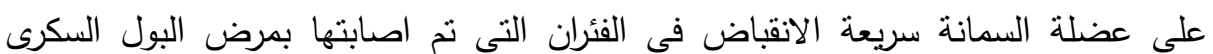

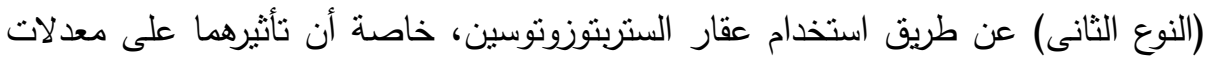
الانقباض فى هذا النوع من العضلات فى النوع الثانى من مرض النقان البول السكرى لم يتم

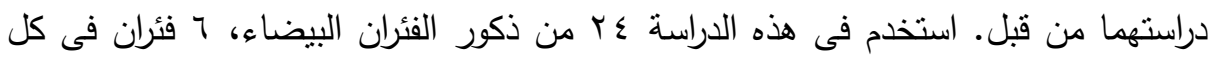

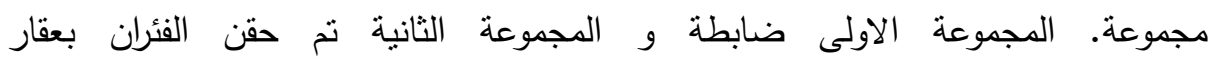

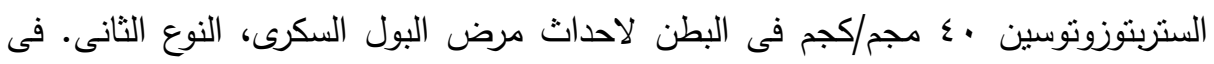
المجموعة الثالثة تم احداث مرض البول السكرى كما فى المجموعة الثانية ثم تم حقن الفئران

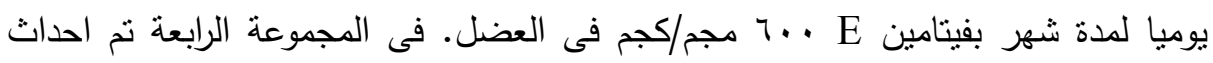

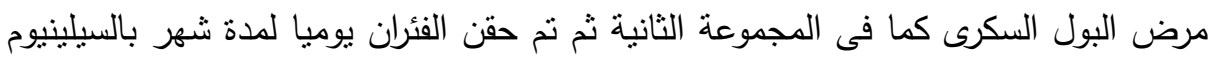

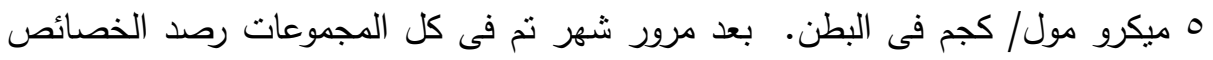

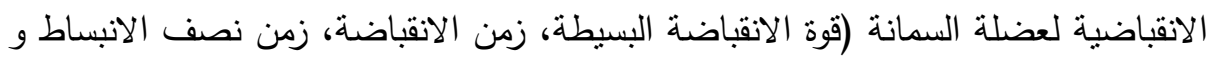

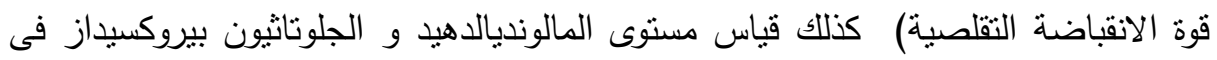
نفس العضلة و هما مؤشران لمعدل العوامل الحرة والاكسدة فى العضلة.

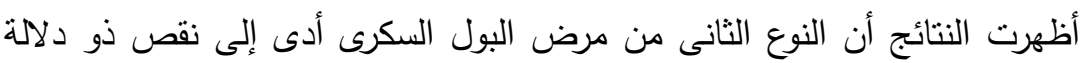

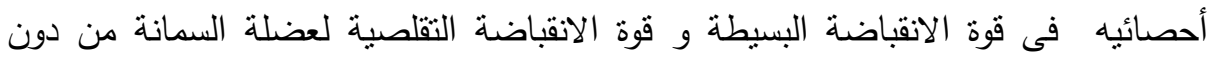

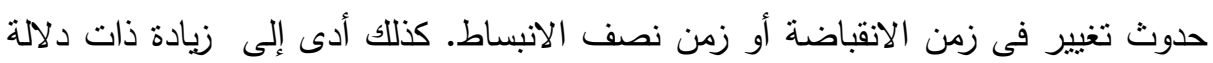

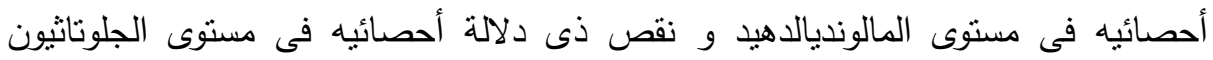
بيروكسيداز فى العضلة. أدى العلاج بفيتامين E و السيلينيوم الى تحسن الخصائس فلئس 
الانقباضية للعضلة كذلك انخفاض المالونديالدهيد و ارتفاع الجلوناثيون بيروكسيداز • و قد كان هذا التحسن افضل احصائيا فى الفئران التى عولجت بالسيلئلينيوم.

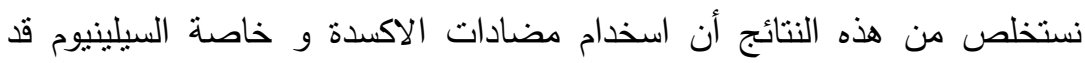

يكون مفيدا فى حماية العضلات سريعة الانقباض من نأثير النوع الثانى لمرض البول

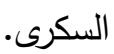

